\title{
A 公司员工忠诚度提升策略探究
}

\author{
刘洁 王树武 马富民
}

烟台南山学院商学院

DOI:10.32629/jief.v2i2.584

[摘 要] 随着市场经济的不断发展, 人作为一种企业资本, 已越来越受到企业的重视, 成为企业核心竞争力之一, 因此打造一支稳定且忠诚 的员工队伍已变得越来越重要。本文对 A 公司员工忠诚度进行探究。首先说明提升员工忠诚度的重要性, 其次表明 A 公司提升员工忠诚度的 影响因素, 最后得出提升员工忠诚度的有效对策。

[关键词] 员工; 忠诚度; 提升对策

\section{$1 \mathrm{~A}$ 公司员工忠诚度提升的重要性}

A 公司为独资公司, 成立于 2018 年, 位于青岛市, 公司注册资本 300 万, 是一家致力于医学影像 $\mathrm{Al}$ 的高科技公司, 专研深度学习技术在医学 影像中的应用。

员工忠诚度是企业发展的强大动力, 员工高忠诚度意味着员工热爱 企业, 愿意在企业积极努力工作, 高度忠诚的员工是企业持续稳定发展 的保障。员工忠诚度对企业的影响主要表现在以下几个方面:

1.1 提高生产和服务效率

效率是人们如何熟练地工作与如何勤奋地工作的乘积, 员工在一个 企业待得越久对企业的业务和工作越熟练, 积累的经验越多, 生产就越 有效率。忠诚度高的员工更熟悉企业的工作流程, 更懂得如可降低成本, 提高生产和服务效率。

\section{2 节约人力资源成本}

如果员工经常流失, 企业就需要不断的招聘新的员工, 组织培训、择 优上岗等等, 这些既浪费了时间精力又增加企业的人力资源管理成本, 而相对于员工忠诚度高的企业不但可以节约这些成本, 反而节省的时间 精力还可以创造更多的价值。

1.3 有利于提升企业形象

员工与企业之间较为稳定的关系是企业团队精神和企业执行力的基 础, 员工忠诚度是企业发展的强大动力, 得人心者得天下。有一流的员 工, 才会有一流的产品, 有一流的产品才会有一流的效益, 有一流的效 益, 才会有一流的企业。高员工忠诚度的企业, 众志成城, 所向披摩。 企业形象得到良好的提升, 社会地位也得到相应的提高。

\section{A 公司员工忠诚度提升的影响因素}

根据 A 公司的企业运营情况, 结合员工的忠诚度进行分析, 将 A 公 司员工忠诚度提升的影响因素分为企业因素和个人因素, 同时又将两个 大类又分为几个小类。

\section{1 企业因素}

从企业自身角度而言, 包括物质收益因素和企业文化因素。物质收 益是员工进入企业工作的基础性条件, 直接影响员工的忠诚度。物质收 益主要表现在两个方面: 薪酬和福利。通过与 A 公司部分员工的交流, 了解到 A 公司的薪酬制度与福利体系很不合理。而从企业文化的角度来 说, 企业没有形成系统的、持续的、鲜明的企业文化, 对员工缺少人文 关怀, 致使员工缺乏归属感, 对企业没有充分认识, 没有形成一种企业 凝聚力。

\section{2 个人因素}

一是员工个体差异。A 公司员工在年龄、婚姻、对企业的认同感以 及对企业的满意度方面存在很大差距。二是员工个人价值观。在基本需 求得到满足后, 员工的需求就会向更高层次发展, 更多的注重个人价值 的实现，而 A 公司员工的价值观受不同因素的影响而有所差别。
当今社会, 每个人都会对个人的职业前景进行规划和预计, 每个员 工都有自己的发展目标。只有当企业的发展和价值与员工的自我发展目 标相一致时, 员工对企业的忠诚才有了必要条件。提升 A 公司员工忠诚 度的对策如下:

3.1 建立合理的薪酬制度和福利体系

首先, A 公司应重新设立薪酬制度, 根据员工的能力与岗位制定合 理的薪酬制度, 使得同等地位的员工有同样的工资, 不同岗位的员工工 资有所区别, 对公司贡献大的员工有与能力相当的薪酬。其次, A 公司 可以在原有五险一金的基础上创新福利发放方式。假如, 公司中有部分 职工没有孩子, 对于子女教育的福利便无法享受, 可以给予职工一定的 自由, 让其可以选择其他福利。此外, 公司还可以针对单身员工提供员 工宿舍、对已婚员工给予住房补贴、定期组织员工体检、不定期的组织 员工团建、组织员工旅游、给予股票期权、提供免费班车、节假日分发 礼品或红包、提供零食下午茶等福利。从而提升专业技术人员的忠诚度。

3.2 塑造以人为本的企业文化

企业文化是现代人力资源管理思想的最高境界和核心, 也是企业追 求的思想内涵。 $A$ 企业应树立以人为本的企业价值观, 以员工为中心点 和出发点来提升员工的忠诚度。

3.3 为员工提供匹配的职业发展机会

良好的发展机会会提升员工的忠诚度, A 公司可以为员工提供技能 培训和透明的晋升渠道。公司可以根据员工的个人条件和背景, 为员工 制定计划和路线并通过培训, 帮助员工提升各种知识和技能, 提供实现 个人专长的计划, 并铺设职业发展的阶梯, 使员工有明确的发展方向, 从而提升员工忠诚度。

总之, 市场的竞争终归是人才的竞争, 而人才发挥作用的基础是对 企业的忠诚。只有员工的忠诚度得到了提升, 企业的效益才会发挥到最 大, 一个企业才可以称得上是成功的企业。

\section{[参考文献]}

[1]巨头公司员工忠诚度[J].中国科技信息,2018(12):6-7.

[2]彭士霞. 员工忠诚度现状调查及提升对策 [J]. 企业改革与管 理,2018(17):87-88.

[3]齐壮力, 程秋梅. 企业员工忠诚度调查与提升策略研究[J].河北企 业,2017(04):145-146.

[4] 沈宇鹏.基于心理契约理论的 IT 企业 90 后技术型员工离职倾向 研究[D].杭州:浙江理工大学,2019,(11):17.

作者简介: 刘洁(1994-), 女, 山东乐陵人, 工商管理专业在读 本科生; 王树武 (1984-), 男, 内蒙古商都人, 讲师, 研究方向: 人力资源管理; 马富民 (1999-), 男, 山东临清人, 山东南山智尚 科技股份有限公司人力资源部, 从事招聘与培训工作。

\section{3 提升 A 公司员工忠诚度的有效对策}

